\title{
Conceptual approach to the management of current assets of an agricultural enterprise
}

\author{
Lyubov Vinnichek ${ }^{1,}$, Dina Badmaeva ${ }^{1}$, and Rakhimjon R. Akhmadov ${ }^{2}$ \\ ${ }^{1}$ Saint-Peterburg State Agrarian University, 196601 Saint-Petersburg, Russia \\ ${ }^{2}$ Tajik National University, Department of state and local governance, 734025, Dushanbe, Republic of \\ Tajikistan
}

\begin{abstract}
The most important direction in the development and implementation of the financial policy of the enterprise is the management of current assets. In the scientific article the conceptual approach based on the theoretical and methodological essence of current assets, which allowed to identify three main directions of management impacts, is proposed and substantiated . Application of conceptual provisions of current assets management is tested on practical data of agricultural enterprises of the agroindustrial complex of the Leningrad region. The use of the proposed approach will allow for quality monitoring of the state and use of the most important components of current assets, to control the provision of the enterprise with inventories, biological and financial assets, to monitor changes in the composition of liquid assets to ensure the market stability of the enterprise.
\end{abstract}

\section{Introduction}

Successful progressive development of agricultural production serves as a basic foundation for the sustainable development of the whole national economic complex of the country. One of the urgent tasks to accelerate the development of agricultural enterprises in modern conditions is to increase their efficiency [1]. Economic activity of Russian enterprises in the agricultural sector is carried out under the negative impact of various external factors, including the tightening of anti-Russian sanctions, deterioration of climatic conditions and aggravation of environmental problems, the emergence of epidemiological situation and the decline in effective market demand. Along with the manifestation of external influences on the efficiency of agricultural production, internal factors associated with the use of various production resources in the business also influence. One of the most important resources in the activity of an agricultural enterprise are current assets, the rational formation and effective use of which has a significant impact on the smooth production process [2]. The specific features of agricultural activities are the seasonality of production, the slowness of capital turnover, high dependence on natural and climatic conditions. This has a significant impact on the size, composition and structure of current assets of an agricultural enterprise, which necessitates a rethinking of approaches to the development of their management policy.

\footnotetext{
*Corresponding author : 1_vinnichek@mail.ru
} 


\section{Materials and Methods}

The object of scientific research was the activity of agricultural enterprises of the agroindustrial complex of the Leningrad Oblast, which is currently on the way to the multipurpose development of the industry to ensure the implementation of the food security program [3]. The agricultural enterprises under study, the main specialization of which is dairy cattle breeding, are also involved in the implementation of this task. When assessing the size according to the criterion of "income per calendar year", all the studied enterprises belong to the small group. When evaluating the size by assets, the enterprises can be divided into three groups: with capital up to 500 million rubles (eight enterprises: JSC Mozhaiskoye, JSC Kipen, JSC Sudakovo, CJSC PP Bolshevik, JSC Kultura-Agro, JSC PP Razdolye, JSC Pobeda, JSC Aleksino); with capital from 500 million to 1 billion rubles (4 enterprises: JSC Rodina, JSC Razdolye, JSC Pobeda, JSC Aleksino). (4 enterprises: JSC Rodina, JSC PP Pervomaysky, JSC PP Plamya, JSC Gatchina); with assets over 1 billion rubles. (2 enterprises: JSC PP Petrovsky, JSC PP Krasnogvardeisky).

In the scientific research methods of statistical study of information, methods of economic analysis of the evaluation of the efficiency of the use of resources, economic-mathematical models of forecasting elements of current assets were used.

\section{Results and Discussion}

The study of theoretical approaches made it possible to identify the economic essence of current assets, determine the most important classification attributes and allocate types of current assets in order to develop management procedures to improve the efficiency of their use at the enterprise.

Based on the accounting approach to the recognition and reflection of current assets, we can conclude that the assets are recognized as such short-term assets, that is, current assets are that part of the property of the enterprise, which has a material and financial nature and which can be transformed into monetary form during one production cycle of duration, as a rule, less than 12 months [4].

The process of agricultural production begins with the purchase of necessary material resources (raw materials, seeds, fertilizers, mixed fodder, petroleum products, spare parts) the supply stage; then purchased raw materials are used directly in the process of creating products - the production stage; after the end of the production process there are finished products, sold further to buyers and customers - the stage of sales and settlements. Current assets are present at each stage of the production process, being in one form or another in a particular form of working capital. The duration of the capital in each form of current assets depends on the specific conditions of economic activity: the greatest period of the working capital in an agricultural enterprise is in the form of raw materials, livestock in growing and fattening, in unfinished production. The specific nature of agricultural production urges the necessity to transform the elements of a complex policy of operative management [5], first of all, the management of current assets of the enterprise. In this case, the main purpose of management is to ensure the optimal balance between the components of working capital [6]. 
Based on the scientific study of the economic essence of current assets and processes of their use, we propose a concept of current asset management, shown in the figure 1.

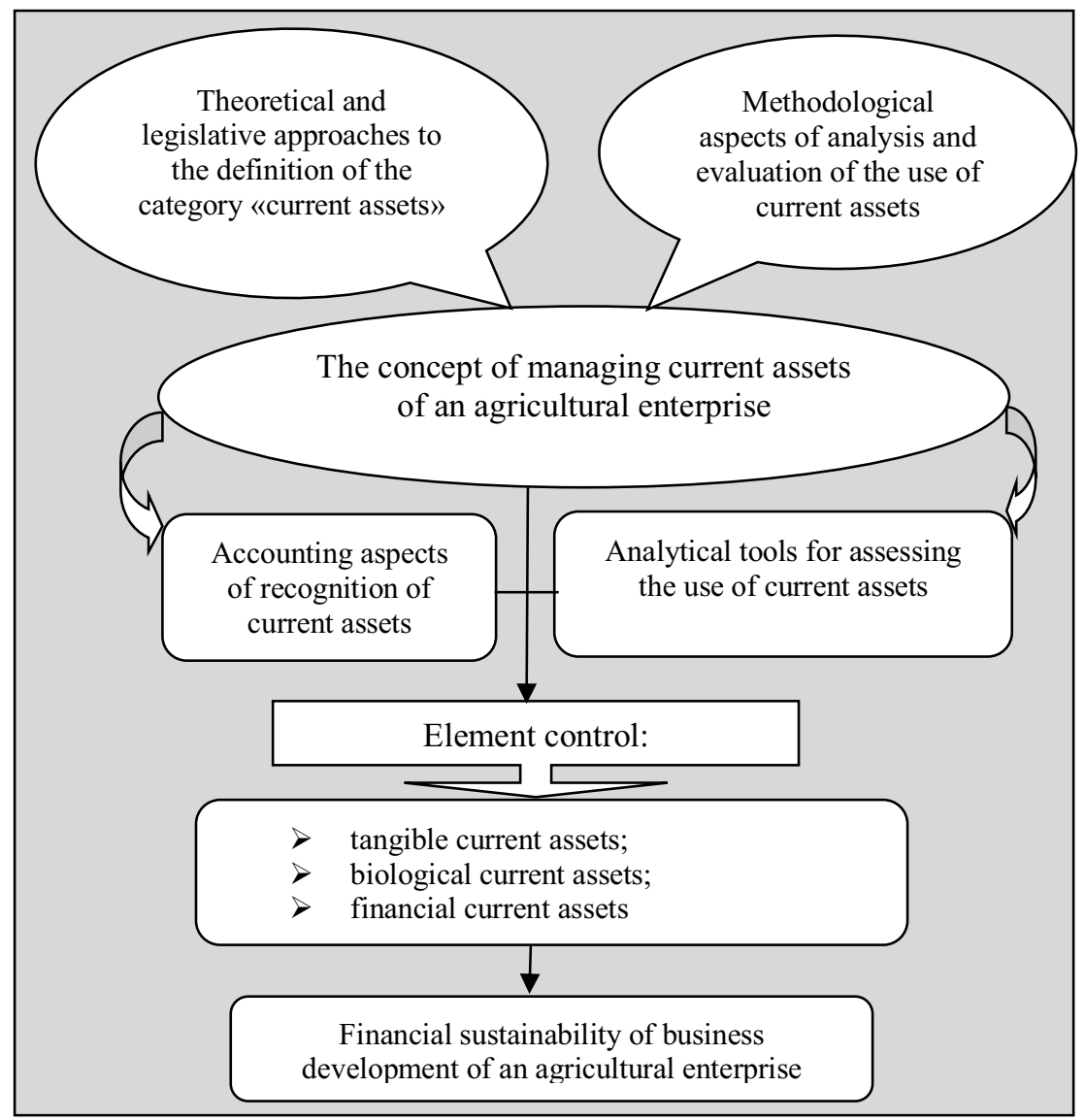

Fig. 1. Author's approach to the concept of management of current assets of the enterprise.

The process of managing current assets of an agricultural enterprise is based on the accounting aspects of the recognition of funds as current assets, as well as on the methods and techniques of analysis and evaluation of the use of these resources in the activities of the enterprise. The basis of the proposed conceptual approach is the allocation of three main and significant groups of current assets in an agricultural enterprise.

Under tangible current assets in the study it is proposed to consider stocks of seeds, feed, fertilizers, materials, spare parts, fuel, finished products, goods. Biological current assets are young animals, growing and fattening animals. Financial current assets are represented by accounts receivable, short-term financial investments and cash assets.

The results of the accounting and analytical procedures of the research allow revealing the problem areas of the functioning of current assets at the enterprise and developing managerial measures to improve the management policy of separate elements of current assets. The achievement of balance in the formation of current assets is a necessary condition for the stable development of the enterprise [7], therefore, ensuring the financial sustainability of agricultural business development is considered to be the ultimate goal of current assets management in the enterprise. 
The greatest attention in the management process should be paid, first of all, to tangible current assets. For example, the cost of mineral fertilizers alone is up to $20 \%$ of the total cost per hectare of agricultural land [8]. As shown by the analysis of the activities of the enterprises under study, raw material inventories along with biological assets account for more than $65 \%$ of all current assets. The system of managing material current assets at an agricultural enterprise is a complex of measures for the production and creation of reserves, operational planning of external supplies of materials, organization of control over the condition and use of inventories (figure 2).

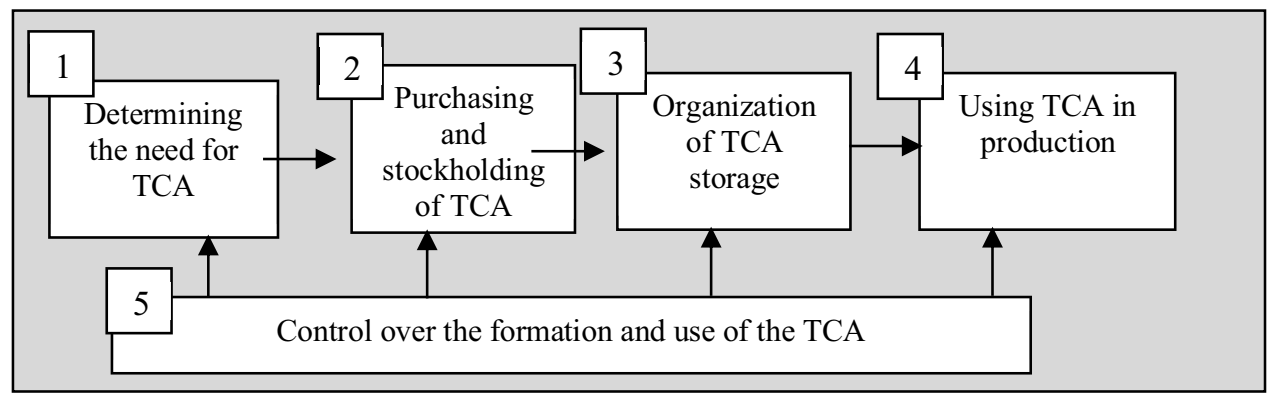

Fig. 2. Stages of the process of managing tangible current assets (TCA) at an agricultural enterprise.

The process of TCA management at an agricultural enterprise includes five main stages:

1) at the first stage the planned need for material circulating assets is determined on the basis of plans of the production program of crop and livestock production for the calendar year. Crop production is the basic branch of an agricultural enterprise both in terms of production and sale of products and in terms of supply of fodder for the livestock industry [9]. The crop production program plans the necessary volumes of seeds, fertilizers, pesticides, spare parts, petroleum products and other materials for sowing, land treatment, and preparation of agricultural machinery and equipment for seasonal work. The livestock program contains the planned volumes of procurement of those types of fodder which are not produced at the enterprise, but are purchased from external suppliers and contractors. It also plans the volume of production costs of petroleum products, spare parts, building materials and other material assets required in the process of economic activity of livestock units;

2 ) the second stage of the management process is a contractual work with counterparties and organization of the purchase of raw materials, materials, spare parts, petroleum products and other values according to the planned volumes in accordance with the production programs of departments. Also at this stage it is organized work on procurement of material current assets during harvesting works, their acceptance, weighing and transfer for storage and consumption;

3) the third stage is storage of tangible current assets, the organization of which is designed to ensure their safety and quality condition;

4) during the fourth stage is the use of tangible current assets in the production process, where the consumption of tangible assets is aimed at the production and sale of agricultural products (works, services) or for consumption for the management needs of the enterprise;

5) the fifth stage of the management process is one of the key stages of management and is devoted to the organization of control over the formation and use of tangible current assets in the implementation of production and financial activities of the enterprise.

Foreign studies of the activity of enterprises have proved that a slowdown in the turnover of inventories has a negative impact on the profitability of assets in dairy companies [10]. The correct organization of the process of TCA control at the enterprise should contribute to the rational and effective use of current assets in accordance with a certain standard, accelerate their turnover and increase the profitability of agricultural production. The 
calculation of the standard of tangible current assets (Tnorm) is proposed according to the algorithm:

$$
\mathrm{T}_{\text {norm }}=(\mathrm{TCAav} \times \mathrm{p}) / \mathrm{I}
$$

where TCAav is the average annual amount of tangible current assets, rubles, $\mathrm{p}$ - period, days; I is the amount of all income, rubles.

The analysis shows the full provision of agricultural enterprises with the necessary amount of tangible current assets. On average for all enterprises the provision indicator increases from $140 \%$ in 2015 to $170 \%$ in 2019.

The most important objectives of the policy of management of biological current assets (BCA) are to ensure productive and breeding work aimed at the systematic and qualitative renewal of the productive herd, as well as the implementation of the planned volume of the production program of livestock breeding and sale of meat products. The analysis showed that the share of biological current assets in enterprises averages up to $38 \%$ of all current assets. In the process of managing biological current assets it is necessary to calculate their normative value and determine the provision of agricultural activities with this element of current assets. The calculation of the standard of biological current assets is recommended as follows:

$$
\mathrm{BCAnorm}=\mathrm{EFd} \times \mathrm{Nbca}
$$

where BCAnorm is the norm of biological current assets, rubles; $\mathrm{EFd}$ is the average daily expenditure of funds, rubles; Nbca is the norm of biological current assets, days.

The average daily consumption of funds is taken in the amount of one day's material costs. The norm of biological current assets is determined on the basis of the average annual value of these elements and the amount of income of the organization for the annual period. According to the results of the analysis it was found that on average for all agricultural enterprises the provision with biological current assets for the period is about $145 \%$.

As a result of the factor analysis, the presence of an inversely proportional relationship between the amount of income generated by the enterprise and the size of the normative turnover of current assets was recorded, which indicates the importance of the speed of turnover of current assets. The higher the rate of turnover, the less current assets are required by enterprises to create agricultural products and obtain economic benefits; the slower the turnover of material resources, the more difficult is the turnover of capital of the enterprise, the higher the normative need for current assets, which requires more and more involvement of funds in production activities.

Within the framework of financial circulating assets management at agricultural enterprises the issues of receivables and cash management are elaborated. The emergence in a market economy of receivables in agricultural organizations is a reflection of normal business practice of management. The agrarian sphere of economy provides buyers with significant deferrals of payment for sold goods [11].

The most important aspect in the system of receivables management is the establishment of the limit of this debt as a whole for the organization, and for individual customers. The limit of accounts receivable for the enterprise as a whole is defined as the sum of available sources of financing of current assets minus the projected amount of inventories, cash, short-term financial investments and VAT on purchased goods [12]:

$$
\mathrm{ARlim}=(\mathrm{OCC}+\mathrm{LL}+\mathrm{SCL}+\mathrm{AP})-\left(\mathrm{AI}+\mathrm{SFI}+\mathrm{AR}_{\mathrm{adv}}\right)
$$

where ARlim is the limited amount of receivables, rubles; OCC is own current capital, rubles; LL - long-term liabilities, rubles; SCL - short-term credits and loans, rubles; AP - accounts payable, rubles; AI - amount of inventories and VAT on purchased valuables, rubles; SFI - 
short-term financial investments, rubles; $\mathrm{AR}_{\mathrm{adv}}$ - accounts receivable in terms of advances given, rubles.

The value less than one indicates that the actual amount of receivables does not exceed the calculated normative value. The value of more than one indicates that the organization exceeds the amount of accounts receivable. In general, all agricultural enterprises under study prefer to restrain the volume of accounts receivable from buyers. The most rigid, in the comparative aspect, is the credit policy of CJSC PP Bolshevik, where by the end of the period under study the actual amount of accounts receivable is only $5.4 \%$ of its normative value. The credit policy of the following companies can also be considered rigid: JSC Kultura-Agro, JSC PP Razdolye, JSC PP Plamya, JSC PP Petrovsky and JSC PP Krasnogvardeisky.

\section{Conclusion}

The effectiveness of the management process of the organization depends on the quality, validity and timeliness of management decisions aimed primarily at the formation and use of current assets of the enterprise. If properly managed, current assets are one of the best sources of cash replenishment, they are necessary for smooth financial and economic activity of the enterprise. Management of current assets belongs to the field of current (operational) decisions of the enterprise and includes management of tangible current assets, biological current assets and financial current assets. The goal of current assets management in an agricultural enterprise is to ensure the optimal size and structure of current assets, the implementation of a smooth and rhythmic production process, which ultimately aims to generate financial stability in the development of agricultural business.

\section{References}

1. Akanova N., Vizirskaya M., Zhdanov V., Vinnicek L. Assessment of financial stability of enterprises of agroindustrial complex with absolute financial indicators // Moscow Economic Journal. № 3. - p. 583-590. (2020)

2. Babenko I.V. Modeling of industrial enterprises circulating capital flow // Proceedings of the 29th International Business Information Management Association Conference Education Excellence and Innovation Management through Vision 2020: From Regional Development Sustainability to Global Economic Growth. p. 1696-1702. (2017)

3. Badmaeva D.G. Economic evaluation of the efficiency of working capital in agricultural enterprises // Journal of MAAO SPbGAU. № 51. - p. 48-55. (2020)

4. Badmaeva D.G., Zolotarev A.A. Accounting and analytical aspects of the formation and use of current assets of the agricultural enterprise // Bulletin of "Proceedings of SPbSAU" № 4 (53). p. 189-195. (2018)

5. Samygin D.Yu., Imyarekov S.M., Tolmacheva N.P., Kargin Yu.I. Strategic management of modern financial requirements in agriculture // IOP Conference Series: Earth and Environmental Science. The proceedings of the conference AgroCON-2019. - C. 012214 (2019)

6. Erdoğan M. Working capital management and firm performance of turkish companies (Book Chapter). Studies on Balkan and Near Eastern Social Sciences. Vol. 3. p. 119-130. (2019)

7. Mann R., Martinovich V., Yakusheva O. The peculiarities of working capital management at agroindustrial enterprises of Ukraine // Problems and Perspectives in Management. p. 260-268/ (2018) 
8. Zhdanov V., Vinnichek L., Vizirskaya M., Zhdanov I. Economical Assessment Mineral Fertilizers Application Systems in Production Conditions // International Conference on Economics, Management and Technologies.Vol. 139. - p. 160-165. (2020)

9. Leshcheva M.G. Features of the analysis in individual industries: a textbook. - Stavropol: Stavropol State Agrarian University. - 176 p. (2014)

10. Gołaś Z. Impact of working capital management on business profitability: Evidence from the polish dairy industr. Agricultural Economics (Czech Republic). p. 278-285. (2020)

11. Kataev V.I., Sushentsova S.S. On the effectiveness of cash management in agriculture // Agrofood policy of Russia. - № 7. - p. 41-45. (2017)

12. Kogdenko V.G. Short-term and long-term financial policy. - Moscow: Unity-Dana. 471 p. (2015) 